\title{
Water quality modeling of the São Joaquim stream, Brazil
}

\author{
Julio Cesar de Souza Inácio Gonçalves' \\ Murilo Senhuki Esposto"
}

\section{Abstract}

Water quality modeling is applied as a supporting tool for water quality management. It is useful in identifying environmental impacts from pollutants discharged into rivers and in predicting self-depuration capacity. This study aimed to simulate the water quality along a stretch in São Joaquim stream basin, in order to identify the main polluting sources in the stream and to propose measures to control pollution. The mathematical model, based on the mass balance in plug flow reactor, was implemented in an electronic spreadsheet. The modeling process involved the following stages: collecting the input data, calibration, sensitivity analysis, uncertainty analysis, and the generation of the scenarios. The calibration of the model has generated $\mathrm{r} 2$ above 0.68 , and it was the indication that the model can explain most of the variance found in the measured data. The wastewater and the stream flow were considered the most sensitive parameters in the model. The uncertainty analysis has shown the probability of the dissolvedoxygen to be higher than or equal to $2 \mathrm{mg} \mathrm{L}-1$, the minimum value allowed for the class 4 , is $5.3 \%$. The main pollution sources in stream are the discharge of untreated domestic wastewater from São Joaquim City, and the surface runoff from the agricultural area. The study has shown that a wastewater treatment station must installed in the basin, in order to remove at least $93 \%$ of the organic matter currently discharged in the stream.

Keywords: Self-depuration; Kinetic coefficients; Surface reaeration; Sensitivity analysis; Uncertainty analysis 


\section{Introduction}

The growing rate of the population has caused a remarkable increase of the demand for natural resources and a continuous process of water resources degradation. In this scenery, studies related to water resources management are essentials. The water quality models are tools used to manage hydric resources. They can be used to allocate polluting sources, to help the decision-making process concerning long- and short-term management, to identify polluting sources, as well as to estimate the maximum pollutant load to be discharged in a water body.

The literature lists a whole variety of models able to be applied (PARK and LEE, 2002; PALMIERI and CARVALHO, 2006; PALIWAL, SHARMA and KANSAL, 2007; HAIDER, ALI and HAYDAR, 2012; MORUZZI et al., 2012; MENEZES et al., 2016; DIGNA et al., 2016; YANG et al., 2017); from simple models such as that by Streeter-Phelps (1925), which just simulate two water quality variables (dissolved oxygen and biochemical oxygen demand) up to the most complex models such as the QUAL2K (CHAPRA and PELLETIER, 2006), which simulates twenty water quality variables. Lindenschmidt (2006) states that complex models are not necessarily the most useful ones, since they require a much larger amount of data to generate the estimates, to calibrate and to verify the parameters. The lack of any of these data may result in unreliable simulations.

Mateus et al. (2015) simulated the Dissolved Oxygen (DO) profile along an urban stretch in Uberaba River basin and identified the main pollution sources. The resulted showed that the Lajes affluent is the main pollution source of Uberaba River and that the probability of Uberaba River to attempt the environmental standard demanded for class $2\left(\mathrm{DO} \geq 5.0 \mathrm{mg} \mathrm{L}^{-1}\right)$ is practically zero, but it could be raised to $75.3 \%$ if the organic polluting load released into the river is decreased in $75 \%$. Bottino et al. (2010) evaluated the water quality of Canha River micro watershed and to calibrated the QUAL2K model with field data. They concluded that despite QUAL2K has some limitations its use is recommended for water resources management and future purposes. Sardinha et al. (2008) applied the QUAL 2K model to evaluate the Meio river auto-purification capacity. They indicated the necessity of secondary wastewater treatment, with 76\% of efficiency. Gonçalves et al. (2012) applied Streter \& Phelps model to evaluate the São Simão stream auto-purification. They showed that the Streeter \& Phelps model allowed identifying the auto-purification zones in this river and indicated the need for primary wastewater treatment, with an efficiency of $30 \%$. Salla et al. (2013) assessed the self-depuration capacity of Jordão River using the QUAL-UFMG model. They highlighted that the deoxygenation by carbon demand over nitrification and the importance of natural re-aeration in the self-depuration process. Teodoro et al. (2013) used the platform QUAL-UFMG on Excel and some equations for determination of dilution and recovery by the effluent discharge. They concluded that the watershed in study has a high capacity for self-depuration, and that its waters are capable of supporting the installation of large-scale enterprises such as slaughterhouses and tanneries.

This study aimed to simulate the water quality along a stretch in São Joaquim stream basin, in order to identify the main polluting sources in the stream and to propose measures to control pollution. This stream is the main supply source in São Joaquim da Barra City and also the main in natura wastewater receptor. The study was not restricted to the simulation of water quality. The sensitivity analysis was conducted to identify the most important parameters of the model. The uncertainty analysis was conducted to present the results of probability occurrence concerning the simulations involving the variable 'dissolved-oxygen'. Besides, scenarios were generated in order to assess the self-depuration capacity of São Joaquim stream and to estimate the minimum wastewater treatment level required to meet the demands in the environmental legislation.

\section{Material and Methods}

\section{Study Area}

São Joaquim stream is tributary of Sapuací Mirim river. These water bodies are inserted in Grande river basin (area of 139,202 $\mathrm{km}^{2}$ ), which is one of the sub-basin forming the Parana river basin (area of 1,192,735 $\mathrm{km}^{2}$ ), according to Marcuzzo (2017). The São Joaquim stream covers an area of approximately $69 \mathrm{~km}^{2}$, and its extension from the headwater to the mouth is $15.47 \mathrm{~km}$. Most of the basin of São Joaquim stream is covered by agricultural areas (68.4\%); just $10 \%$ of it is covered by native vegetation (Marsh and Forest). The urban area covers $14.25 \%$ of the basin's area, and it is mainly responsible for the degradation of São Joaquim stream (Figure 1). The climate in the basin is classified as Aw (Koppen-Geiger's classification), which represents a tropical climate with summer rainfall.

The longitudinal slope in São Joaquim stream is more pronounced in the first $4 \mathrm{~km}$ of the stream, in the headwater region of the basin (it varies from 0.055 to 0.02 $\mathrm{m} \mathrm{m}^{-1}$ ). From this point on, the relief is softened and the slope varies from 0.016 to $0.0041 \mathrm{~m} \mathrm{~m}^{-1}$.

There is latosol prevalence in the basin, and it originates from the decomposition of volcanic rocks. It is a weathered, deep and of good drainage soil (NUNES, 2008).

Three tributaries flow into São Joaquim stream in different points throughout the studied reach: Floresta stream (point T1), Olaria stream (point T2) and Lageado stream (point T3). Among these tributaries, Olaria stream is the most polluted one, since it drains part of the urban area of São Joaquim da Barra City. Besides the three tributaries, São Joaquim stream receives three in natura wastewater discharges (points W1, W2 and W3). The stream also has one water collection point for public supply (point C). According to Decree n. 10755, from November 22nd, 1977, upstream this water collection point, the stream is class 2 (up to $7.9 \mathrm{~km}$ ) and, as for the downstream, it is class 4 (7.9 to $15.47 \mathrm{~km})$. 
Figure 1- Soil use and occupation in the basin and location of the studied points
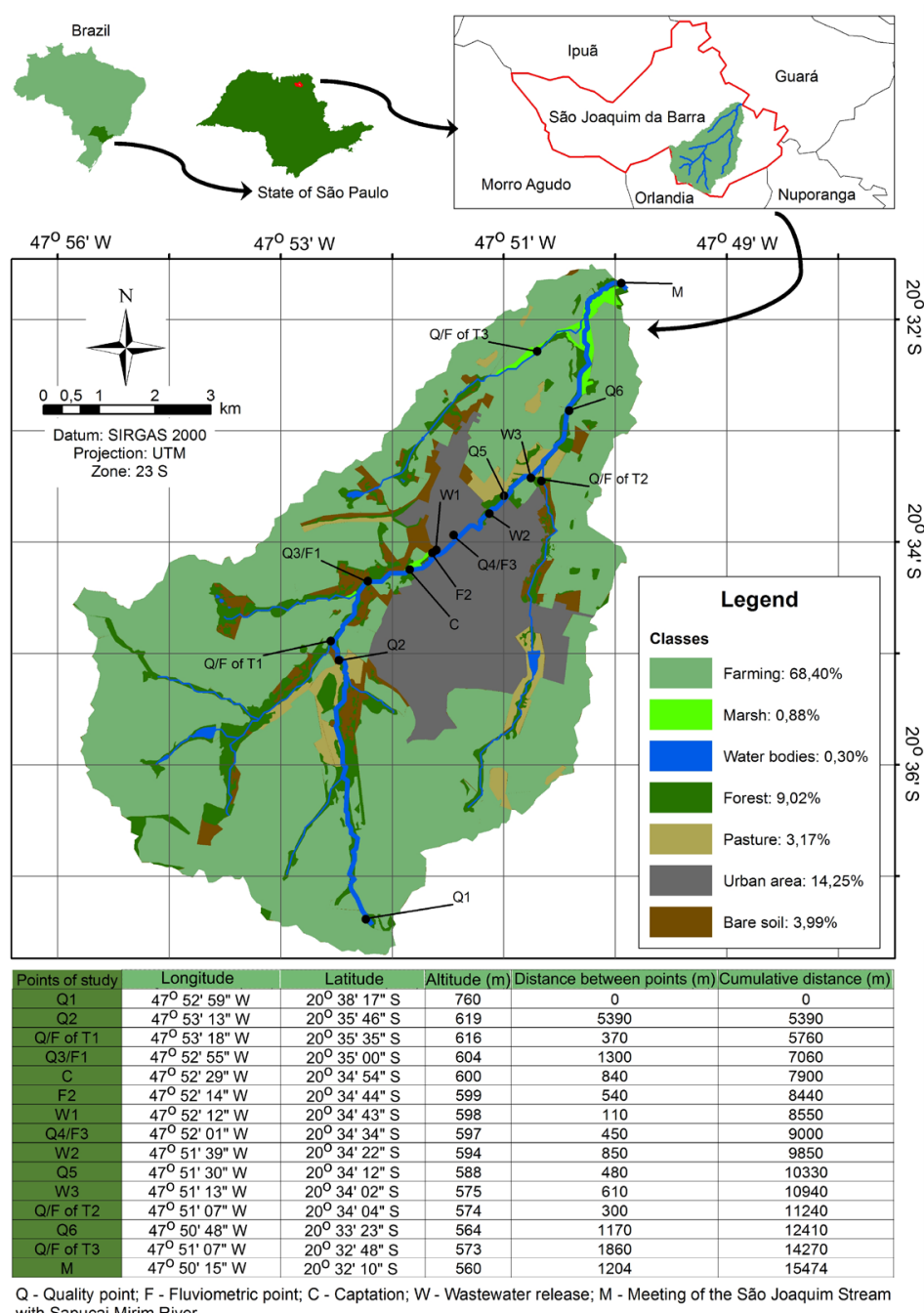

Q - Quality point; F - Fluviometric point; C - Captation; W - Wastewater release; M - Meeting of the São Joaquim Stream

The resolution about the classification of water bodies and the environmental guidelines in Brazil to frame the herein studied stream is National Environmental Council (Conselho Nacional do Meio Ambiente - CONAMA) Resolution 357, from March $17^{\text {th }}, 2005$. On the other hand, the resolution about the conditions and standards for effluent discharges is CONAMA Resolution 430, from May 13th, 2011. Both resolutions, in addition to the aforementioned decree, were used in this study.

\section{Data Collection}

Six collection points were set throughout the longitudinal profile of São Joaquim stream (Q1, Q2, Q3, Q4, Q5 and Q6), besides the points associated with the tributaries (T1, T2 and $\mathrm{T} 3$ ) and with the wastewater discharges (W1, W2, W3) in order to assess the water quality and to calibrate the model. The samples were calculated during the dry period (August, 2015), according to the Brazilian Regulating Standard (Norma Brasileira Regulamentadora - NBR) n. 9897 (ABNT, 1987). The transportation and preservation of the samples followed the NBR n. 9898 (ABNT, 1987). Sixteen physicochemical variables were analyzed, in total.
The organic nitrogen $(\mathrm{ON})$, ammonia nitrogen $(\mathrm{AN})$, nitrate (NN), organic phosphorus (OP), inorganic phosphorus (IP), suspended solids (SS), dissolved solids (DS) and the biochemical oxygen demand (BOD) were quantified according to the "Standard methods for the examination of the water and wastewater" (APHA, AWWA \& WEF; 2005).

Temperature (Tw) and conductivity $(\sigma)$ were measured using Vernier ${ }^{\circledR}$ sensors. A turbidity meter, a pH-meter and an oximeter were used to measure Turbidity $(\mathrm{Tu})$, $\mathrm{pH}$ and the dissolved-oxygen (DO), respectively. All the equipment was previously calibrated.

The presence and absence of total coliforms and Escherichia coli were assessed through qualitative analysis using the methodology of the Colilert ${ }^{\circledR}$ chromogenic substrate, also described by APHA, AWWA and WEF (2005).

The flows in the fluviometric stations ( $\mathrm{F}$ of $\mathrm{T} 1, \mathrm{~F} 1$, F2, F3, F of T2, F of T3) were obtained according to the methodology described by Naghettini (2006). The velocity and the cross-sectional area were measured using a meter current and through bathymetry, respectively. Table 1 shows the main geometric and hydraulic characteristics of the studied stream. 
Table 1 - Geometric and Hydraulic data of the studied points

\begin{tabular}{lccccccccc}
\hline Parameter & $\mathrm{T} 1$ & $\mathrm{~F} 1$ & $\mathrm{~F} 2$ & $\mathrm{~W} 1$ & $\mathrm{~F} 3$ & $\mathrm{~W} 2$ & $\mathrm{~W} 3$ & $\mathrm{~T} 2$ & $\mathrm{~T} 3$ \\
\hline $\mathrm{B}(\mathrm{m})$ & 1.8 & 2.2 & 2.0 & - & 5.8 & - & - & 2.4 & - \\
$\mathrm{A}(\mathrm{m})$ & 0.36 & 0.67 & 0.82 & - & 1.70 & - & - & 0.35 & - \\
$\mathrm{H}(\mathrm{m})$ & 0.20 & 0.31 & 0.41 & - & 0.30 & - & - & 0.15 & - \\
$V\left(\mathrm{~m}^{3} \mathrm{~s}^{-1}\right)$ & 0.086 & 0.181 & 0.123 & $0.006^{*}$ & 0.170 & $0.239^{*}$ & $0.220^{*}$ & 0.102 & 0.016 \\
$\cup\left(\mathrm{m} \mathrm{s}^{-1}\right)$ & 0.24 & 0.27 & 0.15 & - & 0.10 & - & - & 0.29 & - \\
\hline
\end{tabular}

B - Base; A - Area; H - Flow depth; V - Flow; U - Velocity; * Flow obtained through secondary data (São Joaquim da Barra, 2011).

\section{Building the Model}

The mathematical model was implemented in Excel ${ }^{\circledR}$ software in order to simulate seven of the sixteen water quality variables, namely: biochemical oxygen demand, organic phosphorus, inorganic phosphorus, organic nitrogen, ammonia nitrogen, nitrate and dissolved oxygen.

Mass balances were performed in order to find the equations of the model by taking the stream as a plug flow reactor. The first-order kinetic was taken into account in the conversion reactions of the modeled variables. The ordinary differential equations resulting from the balance of each variable were numerically - according to the method by Euler - and analytically resolved. The differential equations are presented in Table 2.

Different integration steps $(\Delta x)$ were tested $(10,100$, 200,300 e $400 \mathrm{~m}$ ) to assess the error between the analytical and the numeric solution using the BOD model as example. Figure 2 shows the absolute error between the analytical and the numerical solution. It is possible noticing that the error linearly increases when the integration step is increased; it reaches $4 \mathrm{mg} \mathrm{L}^{-1}$ at the $400 \mathrm{~m}$ step. In order to have sufficiently small numerical solution errors, it was made the decision of using the $10 \mathrm{~m}$ integration step, which led to an absolute error between the numerical and analytical solution of $0.1 \mathrm{mg}$
Figure 2 - Different integration steps tested in the BOD model

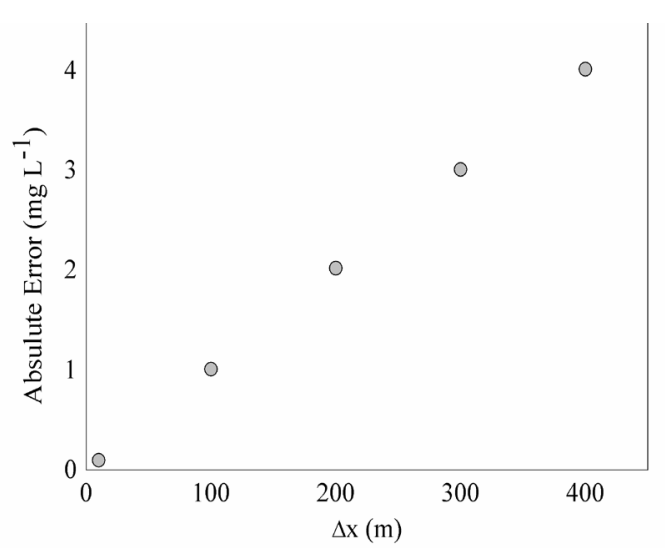

$\mathrm{L}^{-1}$ in the BOD model.

The model was calibrated using the least squares method and by varying the kinetic coefficients of the model according to recommended by Chapra (1997) and Von Sperling (2014).

The adjustments were assessed through the visualization of the generated graphs and through the interpretation of the determination coefficient $\left(\mathrm{r}^{2}\right)$, which was obtained through Equation 1.

Table 2 - Differential equations. Legend: $\mathrm{X}$ - Distance; U - Velocity; $\mathrm{K}_{\mathrm{Poi}}$ - Coefficient of conversion from OP to IP; $\mathrm{K}_{\mathrm{Pso}}$ - Coefficient of sedimentation of OP; $\mathrm{K}_{\mathrm{Noa}}$ - Coefficient of conversion from ON to AN; $\mathrm{K}_{\mathrm{Nso}}$ - Coefficient of sedimentation of ON; $\mathrm{K}_{\mathrm{Nan}}$ - Coefficient of conversion from AN to NN; $\mathrm{K}_{1}$ - Decay coefficient of the organic matter; $\mathrm{K}_{2}$ - coefficient of surface reaeration; Cs - DO saturation concentration, considering the influence of temperature and salinity, according to Pöpel (1979), and of altitude, according to Qasim (1985)

\begin{tabular}{|c|c|}
\hline Variable & Differential Equation \\
\hline OP & $\frac{d C_{O P}}{d x}=-\frac{\left(K_{P_{0 O}}+K_{P s 0}\right)}{U} C_{O P}$ \\
\hline IP & $\frac{\mathrm{d} C_{\mathrm{PP}}}{\mathrm{dx}}=\frac{\mathrm{K}_{\mathrm{poi}}}{U} C_{\mathrm{PP}}$ \\
\hline ON & $\frac{d C_{\text {ON }}}{d x}=-\frac{\left(K_{\text {Noa }}+K_{\text {Nso }}\right)}{U} C_{O N}$ \\
\hline AN & $\frac{\mathrm{dC}_{\mathrm{AN}}}{\mathrm{dx}}=\frac{\mathrm{K}_{\mathrm{Noa}} \mathrm{C}_{\mathrm{ON}}}{U}-\frac{\mathrm{K}_{\mathrm{Nan}} \mathrm{C}_{\mathrm{AN}}}{U}$ \\
\hline $\mathrm{NN}$ & $\frac{d C_{N N}}{d x}=\frac{K_{\mathrm{Nan}} C_{A N}}{U}$ \\
\hline BOD & $\frac{d C_{B O D}}{d x}=-\frac{K_{1} C_{B O D}}{U}$ \\
\hline DO & $\frac{d C_{O D}}{d x}=\frac{K_{2}\left(C_{S}-C_{O D}\right)}{U}-\frac{K_{1} C_{B O D}}{U}-\frac{K_{\text {Nan }} C_{A N}}{U}$ \\
\hline
\end{tabular}


Wherein: $\mathrm{Y}_{\text {obs }}$ is the real value of the parameter; $\mathrm{Y}_{\text {est }}$ is the value estimated through the developed model; and

$$
\mathrm{r}^{2}=1-\frac{\sum\left(\mathrm{Y}_{\mathrm{obs}}-\mathrm{Y}_{\mathrm{est}}\right)^{2}}{\sum\left(\mathrm{Y}_{\mathrm{obs}}-\mathrm{Y}_{\text {obsméd }}\right)^{2}}
$$

$\mathrm{Y}_{\text {obsmean }}$ is the mean of the observed values of the parameter.

The sensitivity and uncertainty analyses were performed through the first-order error method and through the Monte Carlo simulation, respectively, which were described by von Sperling (2014). These analyses were applied to the most critical portion of the stream, which is located after W2. Variations of $+/-50 \%$ in relation to the initial values of the input parameters (stream flow, Vs; wastewater flow, $\mathrm{Vw}$; and temperature, $\mathrm{T}_{\mathrm{w}}$ ) and of the calibrated kinetic coefficients $\left(\mathrm{K}_{1}, \mathrm{~K}_{\mathrm{Poi}}, \mathrm{K}_{\mathrm{Pso}}, \mathrm{K}_{\mathrm{Noa}}, \mathrm{K}_{\mathrm{Nso}}\right.$ $\mathrm{K}_{\mathrm{Nan}}, \mathrm{K}_{2}$ ) were adopted in the sensitivity analysis. The uncertainty analysis was applied to the $\mathrm{DO}$ variable and the variation percentage rate was $10 \%$ in $\mathrm{U}, \mathrm{H}, \mathrm{Vs}$, and $\mathrm{Vw} ; 20 \%$ in $\mathrm{U}, \mathrm{H}, \mathrm{Vs}$, and $\mathrm{Vw}$; and $50 \%$ in $\mathrm{K}_{2}$. Similar values were used by Mateus et al. (2015).

\section{Assessed Scenarios}

Two scenarios were generated aiming at helping interpreting the impacts on São Joaquim stream, and also at developing strategies able to be used in this water body's recovery.

Scenario 1 took into consideration the fictional condition of prolonging the water body until it becomes capable enough to naturally recover. The same features of the last portion to be modeled was kept, and other tributaries or discharges in the main course were not taken into account. This assessment was applied to the $\mathrm{DO}$ and $\mathrm{BOD}$ variables. As for DO, the stream was extended until de concentrations became equal to that found in Q1. Regarding the BOD, the stream was extended until the concentrations became equal to the maximum limit allowed for such variable in class 2, according to CONAMA Resolution 357 (BRASIL, 2005), namely: equal to $5 \mathrm{mg} \mathrm{L}^{-1}$.

Scenario 2 considered that all the wastewater produced in the urban area was taken to a Wastewater Treatment Station (Estação de Tratamento de Esgotos - ETE), which discharges its effluent in a single point, in position W1. It was also considered that the ETE is composed of an anaerobic reactor (UASB) followed by an aerobic reactor (activated sludge), and removal efficiency $93 \%$ in the BOD; $35 \%$, in the total phosphorus; and $60 \%$, in the total nitrogen, according to Von Sperling (2014). The DO in the effluent from the station was considered equal to $4 \mathrm{mg} \mathrm{L}^{-1}$.

\section{Results and Discussion}

\section{Water Quality Assessment}

There were total coliforms and Escherichia coli in all samples, including in those from points that did not receive wastewater discharges, such as Q1. Such fact is associated with the existence of free-living coliforms in the soil and on the plants, as well as with the presence of Escherichia coli in the feces of bovines, since a great portion of the soil is used for farming. There were cattle close to the river source during the fieldwork (DIAS and TAVARES, 2012).

The water temperature increased by $4.8^{\circ} \mathrm{C}$ throughout the water body (from 23.5 to $28.3^{\circ} \mathrm{C}$ ). Such increase is associated with the wastewater discharges (W1, W2, W3), which have presented the following temperatures: 30.2 , 30.0 and $30.8{ }^{\circ} \mathrm{C}$, respectively. The water temperature is an extremely important variable for the water quality modeling, since it affects many vital processes responsible for the balance of the aquatic ecosystem (GONÇALVES and GIORGETTI, 2013). Figure 3 shows the water quality variables assessed in São Joaquim stream, and in its tributaries and pollution sources.

The conductivity presented longitudinal variation in São Joaquim stream, it presented the lowest value in point Q1 $\left(38 \mu \mathrm{S} \mathrm{cm}^{-1}\right)$, and the higher one in point Q6 $\left(387 \mu \mathrm{S} \mathrm{cm}^{-1}\right)$, which is located in the downstream of the urban area. Although the conductivity variation may be associated with the metabolism of the aquatic medium and with the weathering of the rocks, it is consensus that the increase in the values is linked to domestic wastewater discharges (W1, W2 and W3) and to pollutants resulting from agricultural activities performed in the basin (GONÇALVES et al., 2012). The 'dissolved solids' variable presented behavior similar to that of the conductivity, and the lowest value was found in point Q1 (69 $\left.\mathrm{mg} \mathrm{L}^{-1}\right)$; and the highest one, in point Q6 $\left(730 \mathrm{mg} \mathrm{L}^{-1}\right)$. This relation was also observed by Alves (2010).

It is estimated from the data in Table 1 and in Figure 2 that São Joaquim stream receives 12.3 tons of suspended solids in a daily basis. These solids result from discharges W1, W2 and W3. Despite the high load of solids, the variable 'turbidity' did not exceed the limit set by the CONAMA Resolution 357 (BRASIL, 2005). Such result can be associated with high rates of suspended-solids sedimentation, since the flow speed in São Joaquim stream is low.

Regarding the effluent discharge patterns, none of the three discharges considered in the present study respected the requirements in the legislation concerning the BOD variable. All values were above the maximum value allowed (MVA), $120 \mathrm{mg} \mathrm{L}^{-1}$. Since there was no treatment, there was no minimum removal of $60 \%$, as shown in CONAMA Resolution 430 (Brasil, 2011).

As for the nitrogen, it was noticed that the ammonia form has presented the highest variation throughout São Joaquim stream, due to the discharges from the W1, W2 and W3 polluting sources. According to Metcalf and Eddy (2003), the concentration of ammonia nitrogen in the domestic wastewaters vary from 12 to $50 \mathrm{mg} \mathrm{L}^{-1}$. The ammonia nitrogen concentration in point $\mathrm{W} 2$ was above the MVA $20 \mathrm{mg} \mathrm{L}^{-1}$ described in CONAMA Resolution 430 (BRASIL, 2011). As for the organic nitrogen, the longitudinal variation in São Joaquim stream was not as significant as that of the ammonia nitrogen. Although the W1, W2 and W3 sources helped raising the organic nitrogen concentration, there were other sources able 
Figure 3 - Variables analyzed in the São Joaquim Stream basin
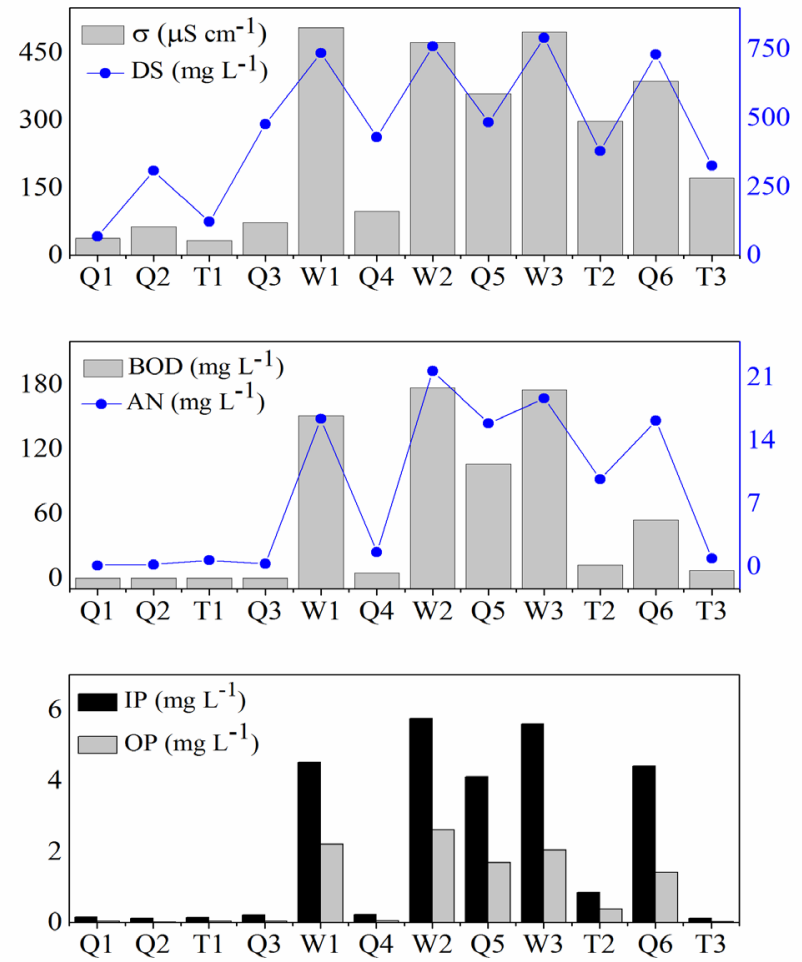

of diffusively adding this element in the water body, namely: cell lysis, decomposition and excretion by the phytoplankton and the aquatic macrophytes (ESTEVES, 2011). Regarding the nitrate, it was observed that the punctual polluting sources did not help raising this element's concentration. According to Piveli and Kato (2005), the domestic wastewaters practically do not contain nitrate. The small nitrate increase throughout the stream may have occurred due to animal droppings and to fertilizers (ESTEVES, 2011). The fertilizers used in agriculture may also have influenced the total phosphorus concentration (TP) in the stream. The points located upstream the wastewater discharges - Q1 $\left(0.18 \mathrm{mg} \mathrm{L}^{-1}\right), \mathrm{Q} 2\left(0.13 \mathrm{mg} \mathrm{L}^{-1}\right)$ and Q3 $\left(0.24 \mathrm{mg} \mathrm{L}^{-1}\right)$ - presented concentrations that have exceeded the MVA $0.1 \mathrm{mg} \mathrm{L}^{-1}$ for the class 2, CONAMA Resolution 357 (BRASIL, 2005). The values of organic and inorganic phosphorus found in discharges W1, W2 and W3 were in accordance with the concentration adopted for untreated domestic wastewater, which, according to Jordão and Pessoa (2014), goes from 2 to $7 \mathrm{mg} \mathrm{L}^{-1}$, and from 3 to $13 \mathrm{mg} \mathrm{L}^{-1}$, respectively.

Regarding the dissolved oxygen, it was observed that the concentration increased from point Q1 to point Q3, in the upstream of the first discharge. Such increase resulted from the transference of oxygen in the air-water interface (surface reaeration), which was more intense in points Q2 and Q3 than in the headwater region (Q1), where the flow and the flow velocity are reduced. The effect of the surface reaeration on the increase in dissolved oxygen concentration is found in the studies by Jha et al., 2004; Queiroz et al., 2015; and Maradei et al., 2015.
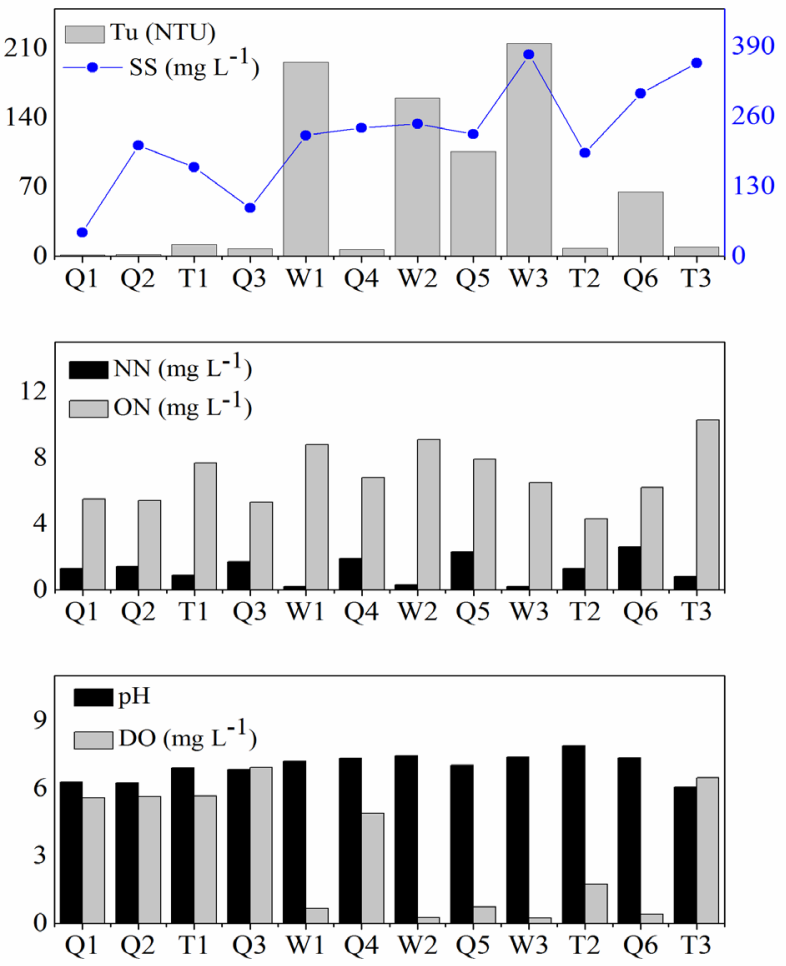

The lowest DO concentration was found in point Q6 (2 $\mathrm{mg} \mathrm{L}^{-1}$ ) and this value was below the minimum allowed for the class 4, according to CONAMA Resolution 357 (BRASIL, 2005). It was observed that the discharges W1, W2 and W3 were the main responsible for reducing DO concentrations in points Q4, Q5 and Q6. Such fact was attributed to two features of the discharges: high organic matter concentration, which is aerobically decomposed; and low DO concentration. The influence of the high organic matter concentration, resulting from domestic wastewater, on the reduction of DO concentrations was observed by Santoro et al. (2016) and Mateus et al. (2015).

The $\mathrm{pH}$ did not undergo significant changes. The highest value recorded in the basin was measured in point T2 (7.88); and the lowest one, in point Q3 (6.05). It indicates that the water was often neutral and that it was within the protection limit set to aquatic life, according to CONAMA Resolution 357 (Brasil, 2005).

\section{Calibrating the Water Quality Model}

The curves describing the behavior of the modeled variables throughout the longitudinal profile of São Joaquim stream are shown in Figure 4.

It was noticed that the concentrations of the modeled variables, except for $\mathrm{DO}$, tended to increase in the portions where São Joaquim stream passes by urban areas, mainly in the downstream of the second discharge, at kilometer 9.85. According to Bottino (2010), the urban area removes the riparian forest, and it discharges the domestic and industrial residues. The most intense surface discharge 
(diffuse load) and the wastewater discharges (punctual loads) within this area were the main responsible for the deterioration of the quality of the water in the stream.

The kinetic coefficient values found during model calibration are shown in Table 3.

Table 3 - Kinetic coefficients found through model calibration

\begin{tabular}{lc}
\hline Kinetic Coefficient & Value (day-1) \\
\hline$K_{\text {Poi }}$ & 0.30 \\
$K_{\text {Pso }}$ & 0.05 \\
$K_{\text {Noa }}$ & 0.25 \\
$K_{\text {Nso }}$ & 0.10 \\
$K_{\text {Nan }}$ & 0.15 \\
$K_{1}$ & 0.45 \\
$K_{2}$ & 7.91 \\
\hline
\end{tabular}

The values of the coefficients $\mathrm{K}_{\mathrm{Poi}}, \mathrm{K}_{\mathrm{pso}}, \mathrm{K}_{\mathrm{Noa}}, \mathrm{K}_{\mathrm{Nso}}$ and $\mathrm{K}_{\mathrm{Nan}}$ are within the limit of the typical values cited by Brown and Barnwell (1987). The decay coefficient of the organic matter $\left(\mathrm{K}_{1}\right)$ may vary due to the wastewater type, from $0.12 \mathrm{day}^{-1}$ in the water bodies receiving domestic wastewater from the secondary treatment station, to 0.45 day $^{-1}$ in water bodies receiving untreated wastewater (VON SPERLING, 2014). The value estimated in the present study was close to the value found by Gonçalves et al. 2012 $\left(0.40\right.$ day $\left.^{-1}\right)$, who have conducted a self-depuration study in São Simão stream (Brazil), where the wastewater was also discharged with no previous treatment. The surface reaeration coefficient values $\left(\mathrm{K}_{2}\right)$ may largely vary depending on the hydraulic and geometric characteristics of the flow such as velocity, depth, declivity and roughness. Values from 0.1 to 4.0 day $^{-1}$ were found by Salla et al. (2014); from 2.3 to 3.0 day $^{-1}$, by Teodoro et al. (2013); and from 2.4 to 6.4 day $^{-1}$, by Salla et al. (2013). Although rare, high values are also found, as it was shown by Pinheiro, Faht and Silva (2012), who obtained $\mathrm{K}_{2}$ values varying form 30.1 day $^{-1}$ to 313.1 day $^{-1}$. The $\mathrm{K}_{2}$ value in the current study was estimated through the empirical equation by de Owens et al. (1964), based on the velocity and flow depth. The $\mathrm{K}_{2}$ was equal to 19.8 day $^{-1}$ in the reach between Q1 and F2; equal to 7.8 day $^{-1}$, between F2 and F3; and equal to 10.64 day $^{-1}$, between F3 and the stream mouth. However, it is assumed that the $\mathrm{K}_{2}$ value found through the calibration of the model is more reliable than that found through empirical equations, since the estimation errors from the application of these equations can be higher than $70 \%$ (MELCHING and FLORES, 1999; GONÇALVES et al., 2017; GONÇALVES et al., 2018).

The deviations resulting from the difference between the measured and the predicted values have produced high coefficient of determination $\left(\mathrm{r}^{2}\right)$, and it indicates that

Figure 4 - Longitudinal profile of the modeled variables throughout São Joaquim stream
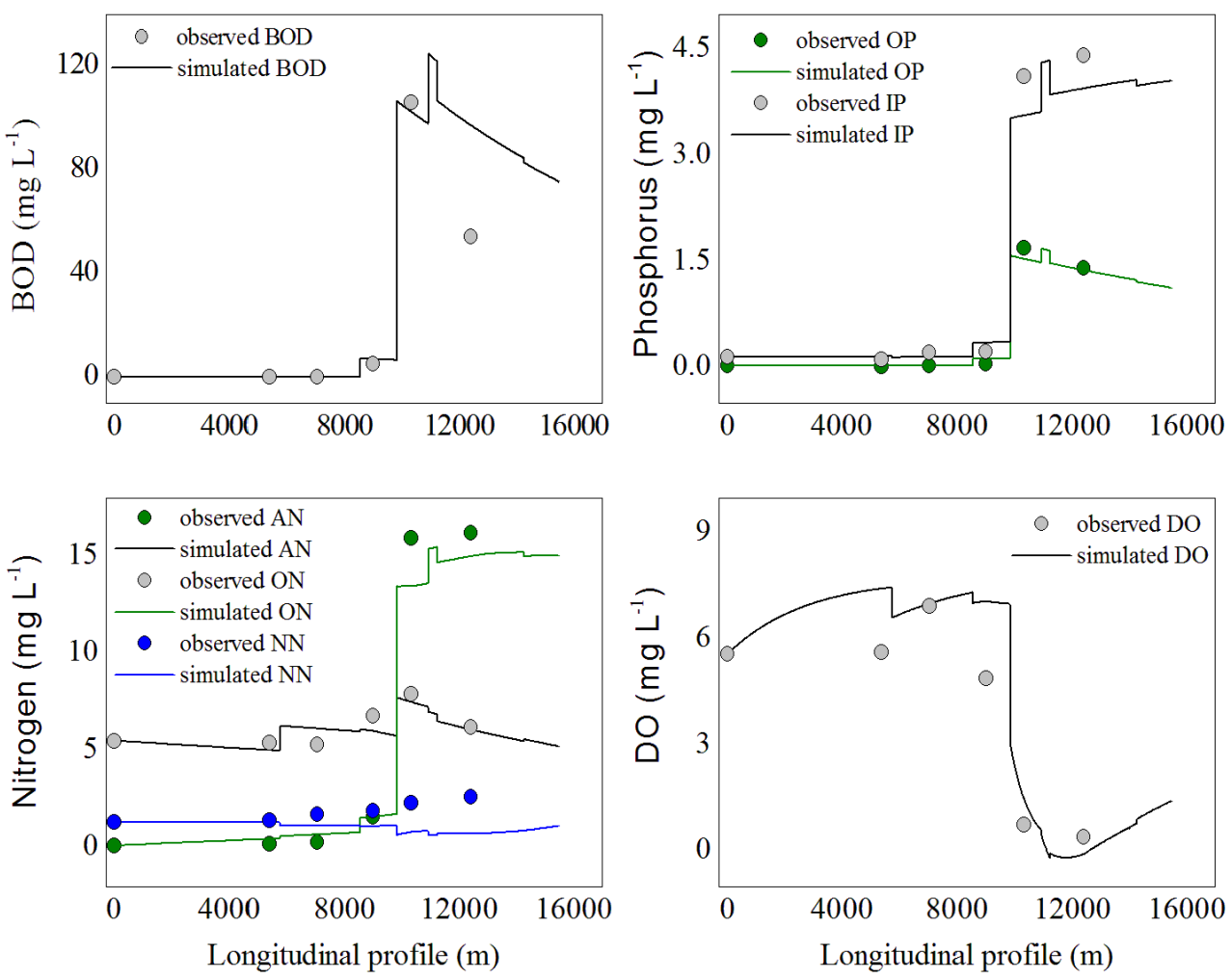
the model is capable of explaining most of the variance found in the measured data (Table 4).

Table 4 - Values of $\mathrm{r}^{2}$ found during the calibration process

\begin{tabular}{lll}
\hline \multicolumn{2}{c}{ Parameter } & \multicolumn{1}{c}{$\mathrm{r}^{2}$} \\
\hline OP & 0.990 & \\
IP & 0.975 & \\
ON & 0.682 & \\
AN & 0.976 \\
NN & -4.178 \\
BOD & 0.805 \\
DO & 0.791 \\
\hline
\end{tabular}

The exception was recorded in the variable 'nitrate', which has presented negative $\mathrm{r}^{2}$. Figure 4 shows gradual increase in the measured data throughout the whole extension of the stream, whereas the modeled values do not follow this behavior. A possible explanation to such phenomenon can be found in the considerations made by Schneider et al. (2011). According to them, the presence of areas reserved for farming and countryside roads may worsen pollution, due to the small vegetation and the high declivities of the watershed; the countryside roads work as water and sediment transportation canals. Possible contaminants such as phosphate and nitrogen composites of fertilizers and pesticides go along with the sediments, besides the coliforms from animal droppings, harvest leftovers and other organic matter sources. As it is known, the soil in the studied basin is used for farming purposes $(68.40 \%)$. Thus, the unsatisfying adjustment between the measured and modeled nitrate concentrations can be attributed to the diffuse pollution derived from these areas. Such diffuse pollution was not taken into consideration in the present study. Besides, the large area reserved for farming along with the reduced forest area (9.02\%) have helped increasing the nitrate in the basin.

\section{Sensitivity and Uncertainty Analyses}

The sensitivity analysis performed through the firs$\mathrm{t}$-order error method has shown that all the modeled variables were more sensitive to the parameter 'flow', either in São Joaquim stream or in the wastewater discharges. The parameters that have mostly affected the DO profile listed in relevance order were: the stream's flow, the wastewater flow, reaeration coefficient, decay coefficient of the organic matter, water temperature and conversion coefficient of ammonia nitrogen into nitrate. Figure 5 illustrates these results. Mateus et al. (2015), and Drolc and Koncan (1996) found the same result, wherein the flows are the most sensitive parameters in the model. According to Mateus et al. (2015), it happens because the flow velocity may affect other coefficients in the model, besides altering the dilution capacity of the organic load. The water quality in less polluted water bodies becomes sensitive to the kinetic coefficients of the model, as it was shown by Fan et al. (2012), who have conducted the sensitivity analysis in the Tan-Sui river, in Taiwan.

Figure 6 presents the frequency distribution of the minimum DO values produced through the Monte Carlo simulation in the reach between kilometers 9.85 and 10.32. There is $5.3 \%$ probability of having minimum DO equal to or higher than $2 \mathrm{mg} \mathrm{L}^{-1}$, which is the mi-

Figure 5 - Sensitivity analysis in the model
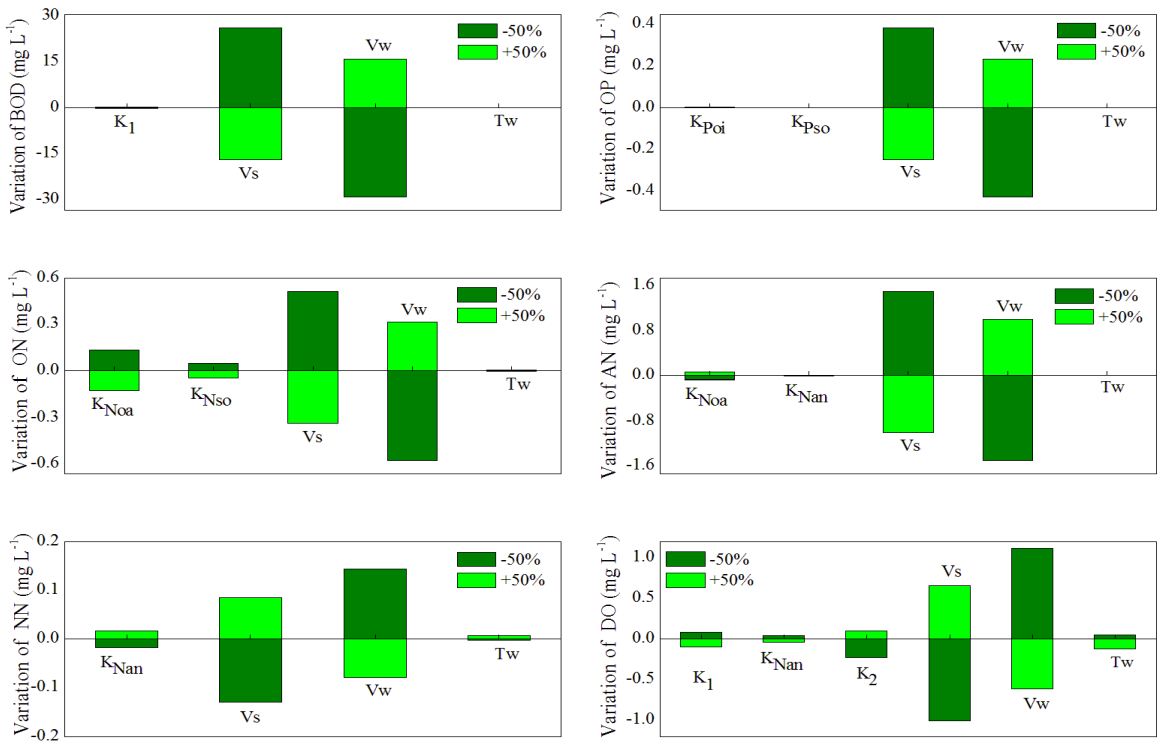
Figure 6 - Accumulated frequency distribution of the minimum DO

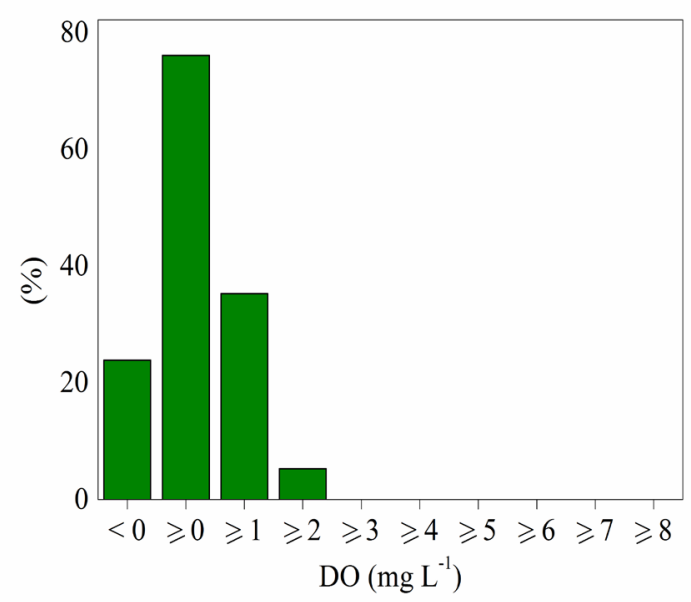

nimum value allowed by the CONAMA Resolution 357 (BRASIL, 2005). Thus, the assumption that São Joaquim stream does not even meet the standards set to class 4 in the analyzed reach has $94.7 \%$ chances to be correct.

\section{Scenarios}

The result of scenario 1 is shown in Figure 7. In order to São Jaquim stream to recover its initial DO concentration $\left(5.57 \mathrm{mg} \mathrm{L}^{-1}\right)$, it should be $45.2 \mathrm{~km}$ long, and such extension would represent approximately 2.92 times its original length. As for BOD, in order to the water body to have concentration lower than $5 \mathrm{mg} \mathrm{L}^{-1}$, which is the acceptable value for class 2 according to the CONAMA Resolution 357 (BRASIL, 2005), it should be $51.4 \mathrm{~km}$ long, an extension that would represent approximately 3.32 times its original length. According to Sardinha et al. (2008), the distance needed for self-depuration is often longer than the physical distance of the water body. These authors have concluded that the Meio stream (Brazil) would need $5 \mathrm{~km}$ after its mouth to have its DO concentration back to $5 \mathrm{mg} \mathrm{L}^{-1}$, in order to reach the clean water zone stage again.

The result of scenario 2 is shown in Figure 8. The minimum DO value was $4.2 \mathrm{mg} \mathrm{L}^{-1}$. This value regards the reach where the stream is class 4 (minimum value allowed $2.0 \mathrm{mg} \mathrm{L}^{-1}$ ). Thus, the present scenario enabled concluding that if São Joaquim da Barra City had a treatment station presenting these treatment efficiencies, the standard required by the environmental legislation would be fulfilled. The CONAMA Resolution 357 (BRASIL, 2005) does not set limits for the BOD, NA, NN and TP variables for the class 4 . Therefore, it is noticeable in Figure 8 that TP was the only variable that did not meet the requirements demanded by the environmental legislation, since the simulated concentration was higher than the maximum concentration allowed for class 2 . However, the high TP concentration within this reach of the stream was not caused by the wastewater produced in the city. Thus, it is assumed that the total phosphorus concentration in the first kilometers of the São Joaquim stream may be reduced by increasing

Figure 7 - The necessary extension for São Joaquim stream to naturally recover

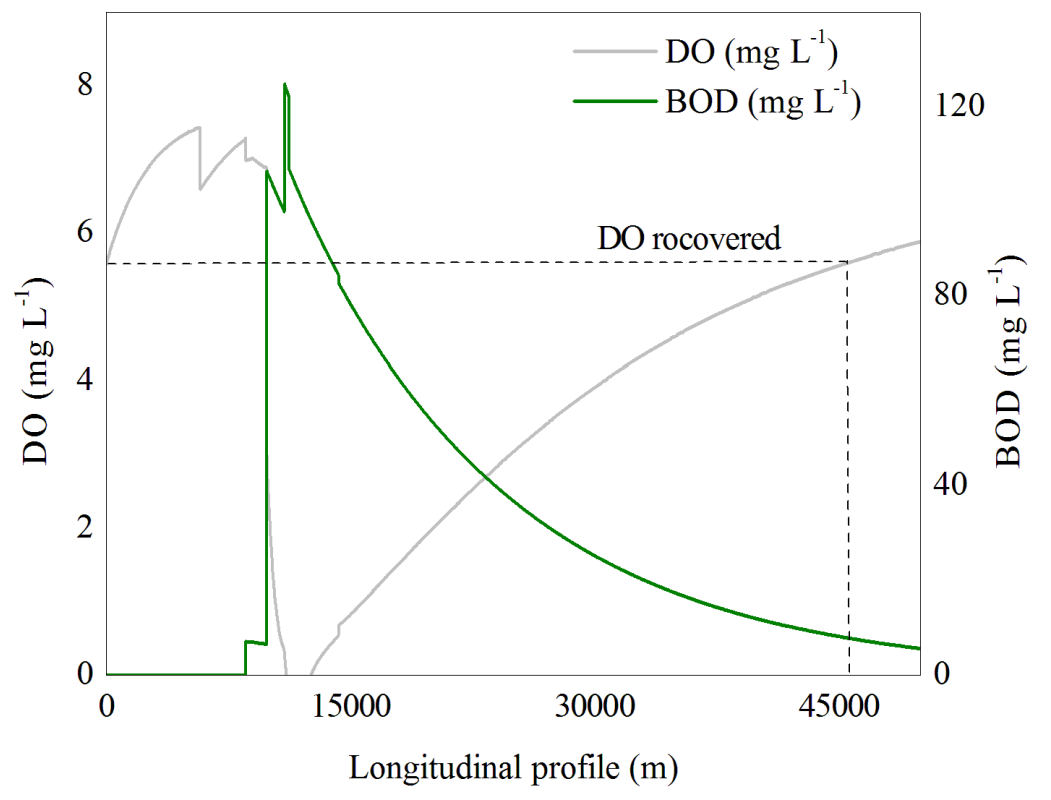


Figure 8 - Scenario 2: simulation considering the treatment station
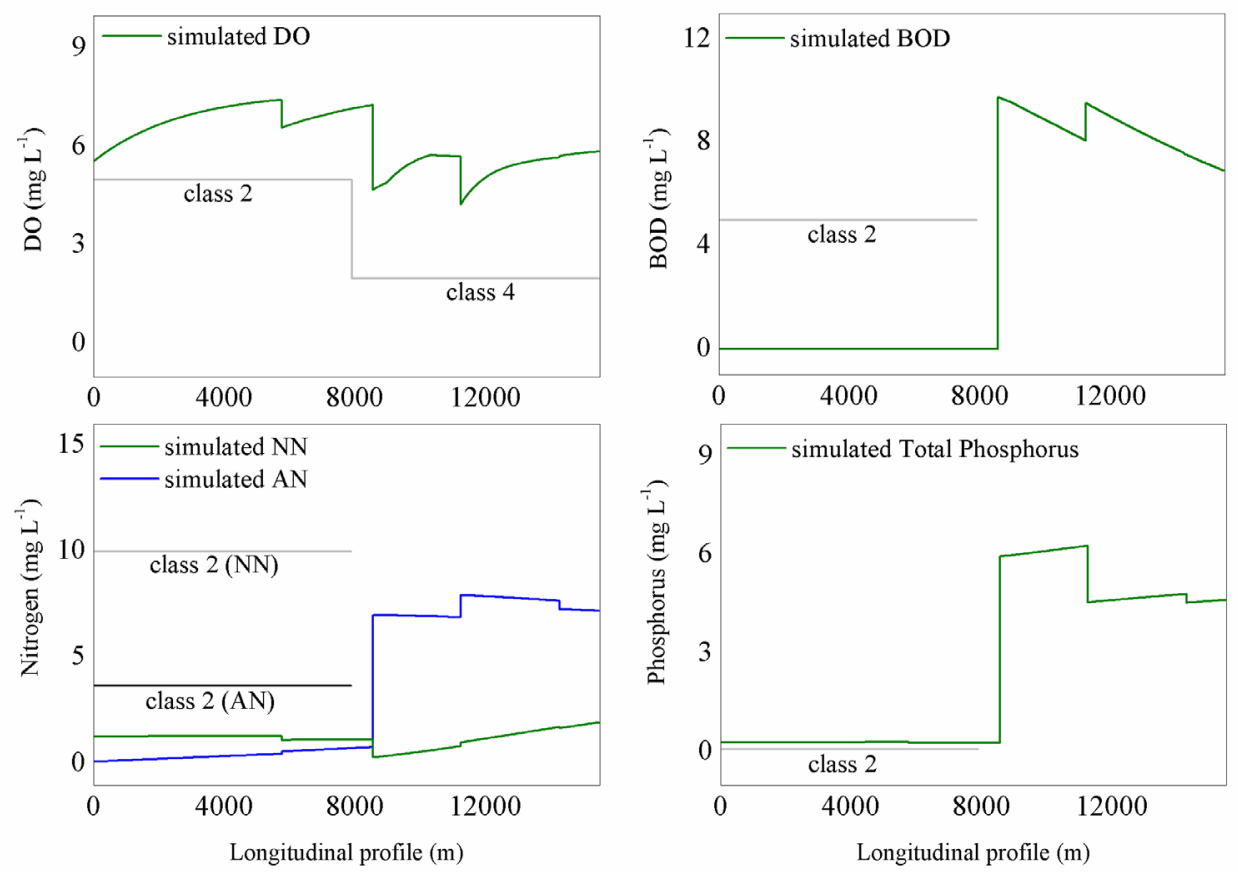

the riparian forest area in the basin, because it would reduce the input of diffuse pollutants resulting from agricultural activities, as it was suggested by Cunha et al. (2010).

The water quality assessment and modeling process in São Joaquim stream, as well as the assessment of the soil use and occupation in the basin, have supported the following conclusions and recommendations:

The anthropic activities in the watershed have worsen the water quality in São Joaquim stream, mainly due to the untreated wastewater discharges and to the surface flow from the urban area and from the agricultural activities conducted in the area. Both the quality standards set to water bodies and to the discharge of effluents were not met.

During the dry season, the self-depuration capacity of the discharges in the stream is insufficient to meet the needs of São Joaquim da Barra County. The scenario concerning the elongation of the water body corroborates such conclusion, and it shows that the stream should be much longer in order to water body to have an effective self-depuration.

The main parameters in the model were stream and wastewater flow, since the model undergoes significant changes when the values of these parameters are changed. Thus, when the input data collection is done, it is worth paying special attention to the flows in order to optimize the resources available for this type of study.

Two activities will have to be implemented in the basin in order to have the standards required by the Brazilian

environmental legislation met: extending the riparian forest area along the longitudinal profile of São Joaquim stream and installing a wastewater treatment station to remove at least $93 \%$ of the organic matter.

It is also recommended assessing the model and using flow data and quality references from other times of the year, such as the rainy season.

It is expected that the information provided by the present study is used by local public authorities as an instrument to recover the water quality in São Joaquim stream.

\section{Acknowledgment}

The present study was developed due to the support from São Joaquim da Barra City Hall and to the help from the Environmental Engineering Department, Food Engineering Department and Chemical Engineering Department of Federal University of Triângulo Mineiro, which have provided the necessary materials for the conduction of the experiment.

\section{References}

ALVES C. Tratamento de águas de abastecimento. 3 th ed. Porto: Publindústria; 2010. 
APHA AWWA, WEF. Standard methods for the examination of water and wastewater. 21st ed. Washington: D.C; 2005. 1368 p.

ASSOCIAÇÃO BRASILEIRA DE NORMAS TÉCNICAS. NBR 9897: planejamento de amostragem de efluentes líquidos e corpos receptores. Rio de Janeiro, 1987.

ASSOCIAÇÃO BRASILEIRA DE NORMAS TÉCNICAS. NBR 9898: preservação e técnicas de amostras de efluentes líquidos e corpos receptores. Rio de Janeiro, 1987.

BOTTINO F, FERRAZ IC, MENDIONDO EM, CALIJURI MC. Calibration of QUAL2K model in brazilian micro watershed: effects of the land use on water quality. Acta Limnologica Brasiliensia [internet]. 2010 [cited 2018 dec 20]; 22(4): 474-485. Available from: http://www. scielo.br/scielo.php?script=sci_arttext\&pid=S2179975X2010000400011.

MINISTÉRIO DO MEIO AMBIENTE; Conselho Nacional do Meio Ambiente. Resolução CONAMA 357/2005 Classificação dos corpos de água e diretrizes ambientais para o seu enquadramento. Brasília (Brasil): Ministério do Meio Ambiente; 2005. Available from: http://www2. $\mathrm{mma}$. gov.br/port/conama/legiabre.cfm?codlegi $=459$ [cited 2018 dec 20].

MINISTÉRIO DO MEIO AMBIENTE; Conselho Nacional do Meio Ambiente. Resolução CONAMA 430/2011 Condições e padrões de lançamento de efluentes. Brasília (Brasil): Ministério do Meio Ambiente; 2011. Available from: http://www2.mma.gov.br/port/conama/legiabre. cfm?codlegi=646 [cited $2018 \mathrm{dec} 20]$.

BROWN L, BARNWELL JUNIOR TO. The enhanced stream water quality models QUAL2E and QUAL2EUNCAS: documentation and user manual. [Report EPA/600/3-87/ 007]. Athens: U.S. Environmental Protection Agency; 1987.

CHAPRA SC. Surface water-quality modeling. 1 st ed. Long Grove: Waveland Press; 1997.

CHAPRA SC, PELLETIER GJ, TAO H. QUAL2K: a modeling framework for simulating river and stream water quality, version 2.04. [documentation and users' manual]. Medford: Civil and Environmental Engineering Dept., Tufts University; 2006.

CUNHA DGF, BOTTINO F, CALIJURI MC. Land use influence on eutrophication-related water variables: case study of tropical rivers with different degrees of anthropogenic interference. Acta Limnologica Brasiliensia [internet]. 2010 [cited $2018 \mathrm{dec} 20$ ]; 22(1): 35-45. Available from: http://ablimno.org.br/doi/10.4322/actalb.02201005. pdf.
DIAS SG, TAVARES LHS. Physical, chemical and microbiological aspects during the dry and rainy seasons in a pond covered by macrophyte used in aquaculture water supply. Acta Limnologica Brasiliensia [internet]. 2012 [cited 2018 dec 20]; 24(3): 276-284. Available from: http:// www.scielo.br/scielo.php?script=sci_arttext\&pid=S2179975X2012000300006.

DIGNA RF, MOHAMED YA, VAN DER ZAAG P, UHLENBROOK S, CORZO GA. Nile river basin modelling for water resources management - a literature review. International Journal of River Basin Management. 2016; (15)1: 39-52.

DROLC A, KONCAN J Z. Water quality modeling of the river SAVA, Slovenia. Water Research. 1996; 30: 2587-2592.

ESTEVES FA. Fundamentos de Limnologia. 3 th ed. Rio de Janeiro: Interciência; 2011.

FAN C, WANG W, LIU KF. Sensitivity analysis and water quality modeling of a tidal river using a modified Streeter-Phelps equation with HEC-RAS-calculated hydraulic characteristics. Environ Model Assess. 2012; 17: 639-651.

GONÇALVES JCSI, GIORGETTI MF. Mathematical model for the simulation of water quality in river using the Vensim PLE Software. Journal of Urban and Environmental Enginnering [internet]. 2013 [cited 2018 dec 10]; 7(1): 48-63. Available from: http://www.periodicos. ufpb.br/ojs/index.php/juee/article/view/15100/9553.

GONÇALVES JCSI, SARDINHA DS, SOUZA ADG, DIBIAZI ALB, GODOY LH, CONCEIÇÃO FT. Avaliação espaço temporal da qualidade da água e simulação de autodepuração na bacia hidrográfica do córrego São Simão-SP. Revista Ambiente \& Água [internet]. 2012 [cited 2018 dec 18]; 7(3): 141-154. Available from: http:// www.scielo.br/pdf/ambiagua/v7n3/v7n3a12.pdf.

GONÇALVES JCSI, SILVEIRA A, LOPES JÚNIOR GB, DA LUZ MS, SIMÕES ALA. Reaeration coefficient estimate: new parameter for predictive equations. Water, Air, \& Soil Pollution. 2017; (228)307: 1-10.

GONÇALVES JCSI, SILVEIRA A, LOPES JÚNIOR GB, DA LUZ MS, SIMÕES ALA, GIORGETTI MF. Evaluation of reaeration by convective heat transfer coefficient. Journal of Environmental Engineering. 2018; 144(2): 0401709.

HAIDER H, ALI W, HAYDAR S. Evaluation of various relationships of reaeration rate coefficient for modeling dissolved oxygen in a river with extreme flow variations in Pakistan. Hydrological Process. 2012; 27(26): 3949-3963.

JHA R, OJHA CSP, BHATIA KKS. A supplementary approach for estimating reaeration rate coefficients. Hydrol. Process. 2004; 18: 65 - 79. 
JORDÃO EP, PESSÔA CA. Tratamento de esgotos domésticos. 7 th ed. Rio de Janeiro: ABES; 2014.

LINDENSCHMIDT KE. The effect of complexity on parameter sensitivity and model uncertain in river water quality modeling. Ecological Modelling. 2006; 190: 72-86.

MARADEI G, VELTRI P, MOROSINI AF, VERBENI B. Laboratory study on the open channel flow reaeration: a dimensional approach. Urban Water Journal. 2015; 12(4): 295-304.

MARCUZZO FFN. Hydrographic watersheds and hydrographic regions in Brazil: area calculation, differences and considerations. In: XXII Simpósio Brasileiro de Recursos Hídricos [Internet]; 2017 dec-jan 26-01; São Paulo, Brasil. 2017 [cited 2018 dec 20]. Available from: http://rigeo.cprm.gov.br/jspui/handle/doc/18492.

MATEUS MV, GONÇALVES JCSI, LOPES JUNIOR GL, OKURA MH. Análise de incerteza e modelagem de qualidade da água do Rio Uberaba, Minas Gerais. Revista Brasileira de Ciências Ambientais [internet]. 2015 [cited 2018 dec 17]; 37: 1-15. Available from: http://abes-dn.org. br/publicacoes/rbciamb/n37/RBCIAMB_n37.pdf.

MELCHING CS, FLORES, HE. Reaeration equations derived from U. S. Geological Survey Database. J. Environ. Eng. 1999; 125:5(407): 407-414.

MENEZES JPC, DE OLIVEIRA LFC, SALLA MR. Incertezas sobre a modelagem matemática de qualidade da água em curso de água urbano. Ciência \& Engenharia. 2016; 25(2): 1-8.

METCALF, EDDY. Wastewater engineering: treatment, disposal and reuse. 4 th ed. New York: MacGraw-Hill; 2003.

MORUZZI RB, CONCEIÇÃO FT, SARDINHA DS, HONDA FP, NAVARRO GRB. Avaliação de cargas difusas e simulação de autodepuração no córrego da Água Branca, Itirapina (SP). Geociências [internet]. 2012 [cited $2018 \mathrm{dec}$ 17]; (31)3: 447-458. Available from: http://www.ppegeo. igc.usp.br/index.php/GEOSP/article/view/7233.

NAGHETTINI M. Mananciais superficiais: Aspectos quantitativos. In: HELLER L, PADUA VL, editors. Abastecimento de água para consumo humano. Belo Horizonte: UFMG; 2016. p. 223-274.

NUNES FC. Pedologia. Bahia: Faculdade de Tecnologia e Ciências; 2008.

OWENS M, EDWARDS RW, GIBBS JW. Some reaeration studies in streams. International Journal of Air and Water Pollution. 1964; 8: 469-486.
PALIWAL R, SHARMA P, KANSAL A. Water quality modelling of the river Yamuna (India) using QUAL2EUNCAS. Journal of Environmental Management. 2007; 83(2): 131-144.

PALMIERI V, CARVALHO RJ. Qual2e model for the Corumbataí River. Ecological Modelling. 2006; 198(1-2): 269-275.

PARK SS, LEE YS. A water quality modeling study of the Nakdong River, Korea. Ecological Modelling. 2002; 152(1): 65-75.

PINHEIRO A, FAHT G, SILVA MR. Determinação do coeficiente de reaeração em rios através do uso do traçador gasoso GLP. Engenharia Sanitária e Ambiental [internet]. 2012 [cited 2018 dec 16]; 17(1): 107-116. Available from: http://www.scielo.br/scielo.php?script=sci abstract\&pid=S1413-41522012000100014\&lng=en\&nrm $=$ iso\&tlng=pt.

PIVELI RP, KATO MT. Qualidade das águas e poluição: Aspectos físico-químicos. 1 st ed. São Paulo: ABES; 2006.

PÖPEL, H. J. Aeration and gas transfer. Delft: Delft University of Technology; 1979.

QASIM S.R. Wastewater treatment plants: planning, design and operation. New York: Holt, Rinehart and Winston; 1985.

QUEIROZ FM, MATOS AT, VON SPERLING M. Estimativa do coeficiente de reaeração da água em canal raso de fundo deslizante. Engenharia Sanitária e Ambiental [internet]. 2015 [cited 2018 dec 16]; 20(1): 79-88. Available from: http://www.scielo.br/pdf/esa/v20n1/14134152-esa-20-01-00079.pdf.

SALLA MR, ARQUIOLA JP, SOLERA A, ÁLVAREZ JÁ, PEREIRA CE, FILHO JEA, OLIVEIRA AL. Integrated modeling of water quantity and quality in the Araguari River basin, Brazil. Latin American Journal of Aquatic Research. 2014; 42(1): 224-244.

SALLA MR, PEREIRA CE, ALAMY FILHO JE, PAULA ML, PINHEIRO AM. Estudo da autodepuração do rio Jordão, localizado na bacia hidrográfica do rio Dourados. Engenharia Sanitária e Ambiental [internet]. 2013 [cited 2018 dec 15]; 18(2): 105-114. Available from: http://www. scielo.br/pdf/esa/v18n2/a02v18n2.pdf.

SANTORO MC, REIS JAT, MENDONÇA ASF. Performance evaluation of optimization models in the determination of wastewater treatment efficiencies inside watersheds. Revista Brasileira de Recursos Hídricos [internet]. 2016 [cited 2018 dec 15]; (21)4: 694-706. Available from: http://www.scielo.br/pdf/rbrh/v21n4/2318-0331rbrh-2318-0331011616031.pdf. 
SÃO JOAQUIM DA BARRA. Lei no 137 , de 10 de novembro de 2011 - Plano Municipal de Saneamento Básico. São Joaquim da Barra (Brasil); 2011.

SÃO PAULO. Decreto no 10755 , de 22 de novembro de 1977 - Enquadramento dos corpos de água receptores do estado de São Paulo. São Paulo (Brasil); 1977.

SARDINHA DS, CONCEIÇÃO FT, SOUZA ADG, SILVEIRA A, DE JÚLIO M, GONÇALVES JCSI. Avaliação da qualidade da água e autodepuração do Ribeirão do Meio, Leme (SP). Engenharia Sanitária e Ambiental [internet]. 2008 [cited 2018 dec 14]; 13(3): 329-338. Available from: http://www.scielo.br/pdf/esa/v13n3/a13v13n3.pdf.

SCHNEIDER RM, FREIRE R, COSSICH ES, SOARES PF, FREITAS FH, TAVARES CRG. Estudo da influência do uso e ocupação de solo na qualidade da água de dois córregos da Bacia hidrográfica do rio Pirapó. Acta Scientiarum. Technology [internet]. 2011 [cited $2018 \mathrm{dec}$ 10]; 33(3): 295-303. Available from: http://periodicos.uem. br/ojs/index.php/ActaSciTechnol/article/view/8385/8385.

STREETER HW, PHELPS EB. A study of the pollution and natural purification of the Ohio River. Public Health Bulletin 146. Washington: U.S Public Health Service; 1925.

TEODORO A, IDE CN, RIBEIRO ML, BROCH SÃO, SILVA JB. Implementação do conceito capacidade de diluição de efluentes no modelo de qualidade da água QUAL-UFMG: estudo de caso no Rio Taquarizinho (MS). Engenharia Sanitária e Ambiental [internet]. 2013 [cited 2018 dec 10]; 18(3): 275-288. Available from: http:// www.scielo.br/pdf/esa/v18n3/1413-4152-esa-18-03-00275. pdf.

VON SPERLING M. Estudos e modelagem da qualidade da água de rios. 1 st ed. Belo Horizonte: UFMG; 2014.

YANG A, DUTTA D, VAZE J, KIM S, PODGER G. An integrated modelling framework for building a daily river system model for the Murray-Darling Basin, Australia. International Journal of River Basin Management. 2017; (15)3: 373-384.

\section{Contribuição dos autores}

Julio Cesar de Souza Inácio Gonçalves

Contribuições substanciais para a concepção do trabalho; redigiu o trabalho e realizou uma revisão substancial; análise e interpretação de dados.

Murilo Senhuki Esposto

Contribuições substanciais para a concepção do trabalho; aquisição; análise e interpretação de dados; redigiu o trabalho e realizou uma revisão substancial. 